\title{
Job's Protest to God in Job 10:1-22 and Its Resonance in Contemporary Suffering in Africa
}

\author{
Luke Emehiele Ijezie
}

\begin{abstract}
This essay addresses the anguish of Job which he pours out in Job 10. Job's anguish is heightened by the fact that he does not know why he is suffering. He directs his protest to God whom he believes knows everything and judges the deepest intentions of human heart. How can God who is the sole author of life and judges rightly be responsible for this unjustifiable torment of the life a righteous man? This study examines the different outpourings of Job's anguished heart and sees them as the epitome of the anguish of a whole group that passes through unjust suffering. The approach adopted in the study is exegetical but with practical pastoral concerns.
\end{abstract}

Keywords: Anguish, innocence, oppression, suffering. 
terms of form, Job 10 is better read as a poetic speech within a narrative whole. It is a lament to God, and in this it resembles the laments in the psalms.

The setting of the speech is the dialogue between Job and his friends. It is actually the second part of the third speech of Job in which Job examines the nature of God and challenges him for an answer to his suffering. Even though the text appears as a lament addressed directly to God it is part of Job's reaction to the rather provocative outbursts of his three friends.

\section{Structure of the TeXT}

A poetic text as Job 10 presents many difficulties at structuring, but given the nature of the present study, the structure is worked out on the basis of theme which indirectly relates to the poetic devices [5].

vv. 1-2: Introduction

vv. 3-7: Accusation of God for Oppressing an Innocent Man

vv. 8-12: Accusation of God for Oppressing His Own Work of Creation

vv. 13-17: Questioning God's Sense of Justice

vv. 18-22: Accusation of God for Unjustly Depriving Him of Peace

\section{ANALYSIS OF THE TEXT}

\section{A. vv. 1-2: Introduction}

In this opening part of the speech, Job expresses his eagerness to pour out the bitterness of his heart [6]. The pain in his heart gives him the audacity to speak to God without fear. In a very emotional tone, he expresses a loathing (nāqetāh) for his own life (hayyîm). The niphal verb nāqetāh ("feeling a loathing for") from root qwt ("to loathe") expresses a deep emotion of disgust or repulsion. The seat or locus of this feeling is the whole personality, represented as nephesh (being, soul, self) [7]. Job's existential condition is represented as his hayyîm (literally "life"). The two words, nephesh and hayyîm, play pivotal roles in the text. The two are not identical in meaning. Life is an antonym of death, and both are the two modes of being of the nephesh. In the creation account in Gen 2:7, God breathes into the Adam that he had fashioned the breath of life (nishmat hayyîm), thus, making him a living nephesh (nephesh hayah). As a matter of fact, the human being is not the only living nephesh. In Gen $1: 30$, every other creature possessing a breath of life is also called a living nephesh. This implies that the word nephesh must have a meaning that makes it possible to apply it to other creatures. The word that suits most here is the word "being". Job's very being, his "self", is his nephesh but his present mode of being is the hayyîm.

What is the sense of the term hayyîm in this context of Job 10:1? The word is used again in v. 12 where Job describes it as one of the divine gifts of grace to him. In 7:7, Job describes his hayyîm as a breath. With the hayyîm, he is a living being, a living nephesh, but without the hayyîm he would become a [8].

${ }^{1}$ A stitch is a single line of poetry, also called a colon or mono-colon, see dead nephesh (nephesh met). His present mode of being, which is his hayyîm, because of its miserable condition, evokes a strong sense of repulsion within his whole nephesh. It becomes clear, then, that Job's whole problem has to do with the hayyîm which has become miserable, disgusting and oppressive. Job has no pride anymore in his hayyîm, as it is as well as dead, and every aspect of it irritates him.

When one is arrested with such sense of the meaninglessness of one's life, what does one do? What does Job do in this miserable, existential situation? He sums his reaction in two emotional outbursts:

"I will let loose on me my complaint."

"I will speak in the bitterness of my being/soul."

Since life has lost all its taste and interest for him, he decides to let loose his anger which he has all along suppressed. The height of it all now is that he decides to direct this bitterness against God whom he considers as the architect of his miserable condition. "I will say to God, 'Do not condemn me, make known to me on what you are contending (rîb) against me'." Job employs the juridical language (rîb) to challenge God to tell him why he has turned against him as if he were a condemned criminal.

This introductory part of the text explains why Job launches the protest against God. With a diminished life, he is no longer afraid to open a case with God frontally, even challenging the divine sense of judgement.

\section{B. vv. 3-7: Accusation of God for Oppressing an Innocent Man}

Here, Job bitterly accuses God of persecuting him. This is strongly worded in four rhetorical questions, which are in vv. $3,4 a, 4 b, 5-7$, and these are articulated in parallel stitches ${ }^{1}$ [8].

Is it a pleasure for you to oppress, [4]

to spurn the work of your hands,

and smile on the plan of the wicked?

Have you eyes of flesh? [1]

Do you see as man sees?

Are your days as the days of a mortal, [5] and are your years as a man's lifetime,

That you seek for guilt in me and search after my sins, [6] Even though you know that I am not wicked, [7] and that none can deliver me out of your hand?

The first question is in synonymous parallelism with the fourth while the second and third questions are also in synonymous parallelism. The chiastic structure which results shows that the central elements are in the second and third questions which put God's divinity into question, asking whether he now sees and judges the way humans do.

The first question (v. 3) interrogates God on why he seems to take pleasure in oppressing and spurning the work of his hands. The two principal words here are "oppress" and "spurn". These represent the main accusations against God. The term "oppress", expressed with the Hebrew verb 'āshaq is used to express the oppression of persons in form of extortion and despoliation [9]. The victims of the oppression 
are usually the poor and such socially defenseless people as the widow, the orphan and the sojourner [9]. Significantly, it is God who usually acts as the defender of the poor in such situations of oppression (Ps 72:4; 103:6; 146:7; Isa 38:14) [9]. The irony now is that the same God is the one doing the oppression. Has God abandoned his role as God?

The other terminology "spurn" is represented by the Hebrew verb mā'as meaning "to despise, have contempt for, reject" [10]. Here in v. 3, God is accused of despising the very work of his hands for no just cause. For Job, this must be on the advice of the wicked for such act hardly befits the divine mode of doing.

The second question (v. 4a) interrogates God on the nature of his sense of sight while the third question (v. $4 \mathrm{~b}$ ) wonders whether the divine mode of seeing things is the same as that of humans. The two questions may be considered as the heart of the whole interrogation. The divinity of God is under scrutiny. Job can understand the limited vision of a human being, here designated by two significant terms, bāsār (flesh, mortal) and 'ěnôsh (man, weakling), which connote fragility and limitations. But since God is supposed to be all-seeing, why does he not see Job's innocence and all his integrity. Job is thus wondering whether God has now changed his mode of seeing.

In the fourth question (vv. 5-7), Job wonders why it takes God such a long time to probe him and discover his sins. Are God's days like those of mortals that it should take him so long to investigate a crime? Is God unsure of his innocence? Once again, Job confesses his innocence: "that I am not wicked" or "that I am not guilty". The verb "to be wicked, act unrighteously, be guity" ( $\mathrm{rsh}^{\mathrm{e}}$ ), connotes the sense of disobedience to God's will or expressed command. Its direct opposite is the verb "to be righteous" (sdq). The two words are used prominently in the book of Job as the friends of Job accuse him of suffering for his hidden wickedness while he not only confesses his righteousness but accuses God of treating the wicked and the righteous in the same manner. In v. 7, Job reminds God of his divine omniscience which entitles him to know that he is guiltless. If God knows this already, one can also not imagine that he has no courage to affirm it since he is all-powerful and no one can deliver from his hand ${ }^{2}$ [11]. It perplexes Job, therefore, why God would so arbitrarily perpetuate the suffering of a man he knows to be innocent and righteous.

The four questions in vv. 3-7 express the deepest human perplexities about God's apparent complicity in the suffering of the innocent. With these agonizing questions, Job seems to infer that either God is enjoying his suffering, as a sadist would do, or that God is jealous of the happiness of a human being.

\section{C. vv. 8-12: Accusation of God for Oppressing His Own Work of Creation}

In this section, Job wonders why God is bent on destroying his own work of creation, knowing very well that the creature is weak and more seriously that he, Job, is innocent. The section is unified by the theme of creation. Job describes with

${ }^{2}$ Aaron Chalmers, in [11] argues that the expression, "no one can deliver (me) from your hand", belongs to a fixed formula, occurring five times in the Hebrew Bible with YHWH as subject (cf. Deut 32:39; Ps 50:22; Isa 43:13; graphic details the way God labored in fashioning him, how he molded him from clay, poured him out like milk, curdled him like cheese ${ }^{3}[12]$, clothed him with skin and flesh and weaved together the whole artwork with bones and sinews. Although Job does not make mention of the womb, his description can be understood as a reference to the womb, being in line with the popular belief that the development of the fetus in the womb is a direct work of God. Two other related texts are Ps 139:13-16 and Ezek 37:6-8. In the text of Ps 139:13-16, the psalmist, just like Job, uses the imagery of the creation of humanity from the earth to describe his own formation in the womb ${ }^{4}$ [13]. In Ezek 37:6-8, which narrates the vision of the dry bones, one also sees the description of the formation of the human body. Karin Schöplin points out that Job 10:11 and Ezek 37:6-8 are unique in the sense that they are the only texts in the Hebrew Bible that give a detailed description of the human anatomy [14]. He acknowledges God's goodness and providential care for him, accompanying him all the way with life (hayyîm) and loving kindness (hesed). With all this laborious work and great indulgence, it sounds incredible that the same God would turn around to destroy the same piece of work and hayyîm. Job makes it clear that his hayyîm is actually God's gift to him. His perplexity is that God would be so eager to undo what he had done.

\section{D. vv. 13-17: Questioning God's Sense of Justice}

But despite his great love, God appears to be bidding his time, waiting for an opportune moment to torture him. The worst is that God's oppression does not care whether one is innocent or wicked. This is well illustrated in v. 15: "If I am wicked, alas for me, and if I am righteous, I will not lift up my head, sated with dishonor, see my misery."

What Job means literally is that his bodily condition makes it impossible for him to raise his head in public. The expression "to lift up the head" (nāsā' hārō'sh))) can have the literal sense of having the strength to raise one's head (to appear in public) or the metaphorical sense of raising the head with pride (appearing with pride in public) [15]. The idea of appearing in public with pride fits in better here. Job's physical condition is so horrible that even if he is declared righteous, he will have no pride to raise his head in public seeing that he carries in his body the marks of dishonor. So, for him, even though being wicked would bring him disaster, being righteous brings equally no gain. At this point he cries out, pathetically, in protest to God, "Bold as a lion you hunt me; you repeat your exploits against me. You renew your witnesses against me and increase your vexation toward me; you bring fresh troops against me" (10:16-17).

\section{E. vv. 18-22: Accusation of God for Unjustly Depriving Him of Peace}

In vv. 18-19, Job questions God why he ever brought him out from the womb and made him live. It would have been better if his fate had been that of moving from the womb to the grave. Since God's loving kindness ends in torture, Job, in his frustration, pleads with God in v. 20 to withdraw and leave him alone to manage his own destiny: "Would He not

Hos 5:15), and expresses the great power of the deity from whose grasp no one can escape

${ }^{3}$ For the cheese allegory, see [12].

${ }^{4}$ See the Comparison between Job 10 and Psalm 139 in [13]. 
let my few days alone? Withdraw from me that I may have a little cheer." God's presence is no longer seen as a saving presence but menacing and dangerous, being seen as a source of discomfort and terror [16]. Again, here one finds a contrast with Psalm 139 where the presence of God is seen as a source of serenity: "You have enclosed me behind and before and laid Your hand upon me. Such knowledge is too wonderful for me; It is too high; I cannot attain to it. Where can I go from Your Spirit? Or where can I flee from Your presence?" (Ps 39:5-7). For Job, instead, God has become as an adversary and his presence has become a nightmare. He knows he has only few days to spend here on earth before he descends to the darkness of the tomb, and he wants to spend these few days with serenity. But this is not possible if God continues to hound him with his presence. So, he wants God to give way so that he may have some peace. This is, no doubt, the talk of desperation, and one finds suchlike outbursts in many speeches of Job (see 3:20-23; 6:8-9; 14:13; etc.). One can expect no less from one who has decided to launch a protest God.

\section{THEOLOGICAL SYNTHESIS}

The text of Job 10 presents the essential points of Job's grievance against God. The central issue is that God has rendered his life so miserable that he takes no pride in it anymore. He now hates his very life to the extent that he wants God to take it away.

Job's bitterness emanates from three religious' convictions. The first is that God is responsible for his miserable state and, in fact, for every human condition whether good or bad. The second is that a righteous person is not supposed to undergo such suffering. Related to this is the third conviction that life is the gift of God, and it belongs to the same God to preserve it. Job's experience until the present misfortune convinced him that God was blessing and protecting his life. Why then did he withdraw his protecting hand? The very thought of it tortures him. With these three convictions, which are based on the traditional doctrine of retributive justice, it becomes perplexing to Job why God would allow him to suffer such misery despite his avowed innocence.

If one agrees with Job's basic convictions, the questions he raises become very difficult to answer. But if one disagrees with Job, one is bound to labor for answers. If one argues that God is not always responsible for evil and human suffering, then Job's accusation of God on this point lacks merit. However, there arises the moral question whether God is not bound to protect one who trusts in him.

Whatever the case may be, God remains a mystery, and his ways are difficult to interpret. His silence and apparent passivity are often inexplicable and difficult to rationalize. While he is ever present, he is also a hidden God [17],[18]. Normal human experience illustrates the fact that bad things often happen to good people and that God does not always shield his faithful ones from suffering. In the face of this life problem, Harold S. Kushner avers, "I no longer hold God responsible for illnesses, accidents, and natural disasters...I can worship a God who hates suffering but cannot eliminate it, more easily than I can worship a God who chooses to make children suffer and die, for whatever exalted reason." [19].

One can appreciate the depth of Job's faith. He was so convinced that his God would always stand by him. As Roland E. Murphy puts it, "His statements of despair are colored with faith, and are never to be seen apart from his faith. This is the verisimilitude that characterizes the author, who is able to experience and express the extremes of despair and hope." [20].

\section{CONTEMPORARY AFricAn RESONANCE OF THE TEXT}

The central point of this text is the issue of a life that has become miserable. How does one react in a situation where life is no longer considered meaningful? How does one react generally to meaninglessness and suffering? What role does God play in the picture?

Life is a central concern in the African society, and the average African is ready to go to any length to enhance life. This is true both ancient traditional Africa and contemporary Africa. Many African languages have names resembling these two names in the Igbo language: ndubuisi ("life is primary"), nduka-aku ("life is greater than wealth"), all showing the centrality of life. Many scholars have made it clear that the welfare of the human person is at the very centre of African religiosity, and all African religious practices are oriented towards enhancing human and earthly life [21], [22]. The centrality of life in the African thought processes helps to understand the peculiar features of African humanism. While God is seen as the source of life, this life is best expressed in human life. As Bénézet Bujo points out, life is the unifying force, and every other thing revolves around this life which is seen as God's gift [23]. All material and spiritual forces are employed to service this life in its tangible and human expression. John S. Mbiti puts it aptly, "To live here and now is the most important concern of African religious activities and beliefs. There is little, if any, concern with the distinctly spiritual welfare of man apart from his physical life. No line is drawn between the spiritual and the physical." [21]. According to Mbiti, "Man's acts of worship and turning to God are pragmatic and utilitarian rather than spiritual or mystical." [21].

A proper consciousness of this basic reality of the African society is very important for any pastoral initiative just as it helps one to see clearly how the experience of Job relates to contemporary Africans. It is a fact that almost every institution in the African society is employed to enhance life, and any institution that is found wanting in this is either directly disqualified or ignored. It is, therefore, understandable that God, religion, politics and other institutional structures are all used for the promotion of life.

The story of Job resembles the many experiences of people in our African societies when misfortune or sickness strikes to threaten the life here and now. The people usually believe that the hand of God is always in their sickness and misfortune just as they also believe that God's hand is in their good fortunes. When one repeatedly becomes a victim of unfortunate experiences, the usual response is to ask what she or he has done to be subjected to such misery.

In the pastoral context, one often finds it difficult to counsel people who are confused about the cause of their suffering. Sometimes, pastoral counsellors' resort to simplistic explanations that aim at momentarily tranquilizing the sufferer or bulling him or her into accepting a dogmatic interpretation that in the long run does not convince. For 
instance, there are such explanations as "God loves you, he will not allow you to suffer." "Suffering is not your portion; only believe and claim good health!" "Claim prosperity!" Possess your possessions!" "Your suffering is as a result of a lingering curse in your family." The last interpretation is very popular today among the Pentecostals, and this has also infiltrated some ranks of the Catholic pastoral interpretation. This has resulted in many sham deliverances and breaking of curses, which often end up creating more problems than solutions for families and individuals. While the genuine Catholic position affirms the presence of a loving and caring Father God who is ever ready to make life better for his children, it also recognizes the reality of suffering in human life and even sees genuine suffering, a suffering emanating from love, as an authentic way of following the crucified Christ. African Christians and victims of unmerited suffering need this type of catechesis as it helps to unite their apparently irrational suffering with suffering of Christ.

The reader of Job may be convinced of the cause of Job's suffering, but daily life experiences do not give one such privileged knowledge. In ignorance of the causes of their misfortune people give interpretations that are popular in the culture. Whatever one may say and however one may preach, the truth is that the average person, and the African in particular, continues to search for a better life here on earth.

\section{CONCLUSION}

The text of Job 10 ends in a way that leaves many questions unanswered. Job does not get answers to his many questions. He ends up wishing for death since life has already lost all its charm for him. We see suffering humanity through the lenses of Job as the daily struggle to explain the pandemic of pain and suffering continues. The alarming degree of misery in Africa and its stubborn character of increasing instead of decreasing are issues that constantly challenge our exegetical and theological inquiries. It is true that the mystery of the Cross and resurrection and the Christian eschatological hopes promise definitive answers and consolation. The great challenge, however, is to present these hopes in a way that the God of life and love is seen to be really present and interested.

\section{REFERENCES}

[1] N. Whybray, Job, Sheffield: Phoenix Press, 2008.

[2] For some studies in this context, see Patrick Adeso, "Sufferings in Job and in an African Perspective: Exegesis of Job 42:1-6," Human Wisdom and Divine Wisdom in the Bible / Sagesse humaine et sagesse divine dans la Bible. Mélanges offerts à S. E. Laurent Monsengwo Pasinya à l'occasion de ses 25 ans d'épiscopat (ed. Jean-Bosco Matand Bulembat; Nairobi: PACE/APECA Publications, 2007) 77-83; Ghislain Tshikendwa Matadi, "De l'épreuve à la sagesse. Le livre de Job lu par un Africaine," Human Wisdom and Divine Wisdom in the Bible / Sagesse humaine et sagesse divine dans la Bible, Mélanges offerts à S. E. Laurent Monsengwo Pasinya à l'occasion de ses 25 ans d'épiscopat (ed. Jean-Bosco Matand Bulembat; Nairobi: PACE/APECA Publications, 2007) 85-99.

[3] For more on this, see J. Crenshaw, "Job, the Book of." Anchor Bible Dictionary. 858-68, 1992.

[4] N. Whybray, Job, Sheffield: Phoenix Press, 2008, 3.

[5] P. Van der Lugt, "Stanza-Structure and Word-Repetition in Job 314," Journal for the Study of the Old Testament, 13(40), 3-38, 1988.

[6] J. T. Wilcox, "The bitterness of Job: a philosophical reading," University of Michigan Press, 1989.

[7] R. A. Di Vito, "Old Testament anthropology and the construction of personal identity," The Catholic Biblical Quarterly, 61(2), 217-238, 1999.

[8] G. E. W. Wilfred, "Classical Hebrew Poetry," A Guide to its Techniques, 12, 1984.

[9] L. Swart, “'̌̌q," NIDOTTE 3, New International Dictionary of Old Testament Theology \& Exegesis (ed. W. A. VanGemeren; 5 vols.; Grand Rapids 1997) 557.

[10] Eugene H. Merrill, “ $m$ 's," NIDOTTE 2, New International Dictionary of Old Testament Theology \& Exegesis (ed. W. A. VanGemeren; 5 vols.; Grand Rapids 1997) 833

[11] A. Chalmers, "There is no deliverer (from my hand) - A formula analysis," Vetus Testamentum, 55(3), 287-292, 2005.

[12] C. Frevel, "Die Entstehung des Menschen: Anmerkungen zum Vergleich der Menschwerdung mit der Käseherstellung im Ijob 10, 10," Biblische Notizen, 130, 45-57, 2006.

[13] W. P. Brown, S. D. McBride, and W. S. Towner, "Creatio corporis and the rhetoric of defense in Job 10 and Psalm 139," God who creates, 107-124, 2000.

[14] K. Schöpflin, "The Revivification of the Dry Bones: Ezekiel 37: 114," Deuterocanonical and Cognate Literature Yearbook, 2009(2009), 67-86, 2009.

[15] M. Cohen, "Etude sémantique des locutions nś' ro's-nś' 'æt-ro’š et nś' 'awôn-nś' 'æt-'awôn en hébreu biblique," Zeitschrift für die alttestamentliche Wissenschaft, 115(1), 54-72, 2003.

[16] W. Gross, "Bedrohliche Gottesnähe als Gebetsmotiv," Gottes Nähe im AltenTestament 65-83, 2004.

[17] S. E. Balentine, "The hidden God: the hiding of the face of God in the Old Testament," 1983.

[18] J. Long, Why Is God Silent When We Need Him the Most? A Journey of Faith into the Articulate Silence of God, $1^{\text {st }}$ edition, Grand Rapids: Zondervan, 1994.

[19] H. S. Kushner, When Bad Things Happen to Good People New York: Schocken, 1981.

[20] W. R. Farmer, "The international Bible commentary: a Catholic and ecumenical commentary for the twenty-first century," Minesota, The Liturgical Press, 1998.

[21] S. Mbiti, African Religions \& Philosophy London: Heinemann, 1969.

[22] E. Ikenga-Metuh, African Religions in Western Conceptual Schemes: The Problem of Interpretation [Studies in Igbo Religion] Ibadan: Claverianum Press, 1985.

[23] B. Bujo, African Theology in its Social Context Original in French, 1986; Nairobi: St. Paul Communications, 1992. 